\title{
Labium Minus
}

National Cancer Institute

\section{Source}

National Cancer Institute. Labium Minus. NCI Thesaurus. Code C12307.

One of the two longitudinal folds of skin located between the labia majora. 